\title{
Hava Körüklerinin Statik ve Dinamik Sönümleme Özelliklerinin Sonlu Elemanlar Yöntemi ile İncelenmesi
}

\author{
Hasan Kasım ${ }^{1 *}$, Erol Özkan ${ }^{2}$, Murat Yazıcı ${ }^{3}$

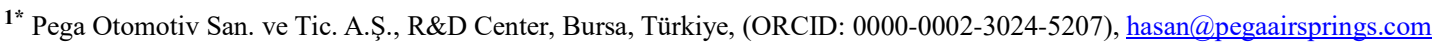 \\ ${ }^{2}$ Bursa Uludag Üniversitesi, Mühendislik Fakültesi, Otomotiv Mühnedisliği Bölümü, Bursa, Türkiye (ORCID: 0000-0002-8382-3461), erolozkan149@gmail.com \\ ${ }^{3}$ Bursa Uludağ Üniversitesi, Mühendislik Fakültesi, Otomotiv Mühendisliği Bölümü, Bursa, Türkiye (ORCID: 0000-0002-8720-7594), myazici@uludag.edu.tr
}

(İlk Geliş Tarihi 15 Mart 2021 ve Kabul Tarihi 30 Mayıs 2021)

(DOI: 10.31590 /ejosat.897413)

ATIF/REFERENCE: Kasım, H., Özkan, E., Yazıcı, M. (2021). Hava Körüklerinin Statik ve Dinamik Sönümleme Özelliklerinin Sonlu Elemanlar Yöntemi ile İncelenmesi. Avrupa Bilim ve Teknoloji Dergisi, (21), 12-22.

Öz

Araç dinamikleri açısından, süspansiyon sistemi, yüksek sürüş hızlarında yol düzensizliklerine karşı iyi sürüş kalitesini ve yol tutuş performansını korumalıdır. Körükler, uzun yıllardır ticari araçlarda ve otobüslerde, sürüş yüksekliğini korumak ve yükten bağımsız olarak araç konforunu artırmak için kullanılmaktadır. Hava yayları malzeme yapısı nedeniyle, çalışma sırasında tek yönlü gerilmelere maruz kalmazlar ve doğrusal olmayan davranış sergilerler. Kompozit yapı, farklı kalınlıktaki iç ve dış kauçuk arasında iki katman olarak zıt açılarda sarılan kord bezinden oluşur. Bu yüzden tek başına yüklemenin neden olduğu değişikliklerin ampirik olarak belirlenmesi zordur. Bu çalışmada hem deneysel hem de sonlu eleman yöntemleri ile havalı süspansiyon sisteminin bir parçası olan hava körüklerinin statik ve dinamik sönümleme özellikleri araştırılmıştır. Statik ve dinamik sönümleme özellikleri belirlenirken, farklı basınç ve deplasmanlardan dolayı körüklerde oluşan reaksiyon kuvvet değerleri kullanılmıştır. Sıkıştırma sonrası geri yaylanma esnasında deneysel ve analitik çalışmalardan elde edilen yay sabitlerinde farklılıklar gözlemlenmiştir. Minimum yüksekliğe ulaşıldıktan sonra geri hareket başladığı anda yay sabitinde yaklaşık \%10'luk bir sapma gözlemlenmiş, sonrasında \%6'dan daha az bir sapma değeri gözlemlenmiştir. Deneysel ve analitik çalışmalarda, anlık yükleme sonucunda elde edilen yay sabitleri arasındaki sapma değerleri \%4'ün altında hava körüklerinde FEA analizinin etkin bir şekilde kullanılabileceği görülmüştür.

Anahtar Kelimeler: Hava körüğü, Sonlu Elemanlar Analizi, Kord-kauçuk kompozitler, Hiper elastik malzeme, Sürüş konforu.

\section{Examination of the Static and Dynamic Damping Properties of Air Springs by Method of Finite Elements}

\begin{abstract}
In terms of vehicle dynamics, the suspension system must maintain good ride quality and handling performance against road irregularities, especially at high driving speeds. Air springs have been used in commercial vehicles and buses for many years to maintain ride height and increase vehicle comfort regardless of load. Due to the air springs' material structure, they are not subjected to unidirectional stresses during operation and exhibit non-linear behavior. The composite structure consists of four layers with cord fabric wrapped at opposite angles as two layers between inner and outer tires of different thickness. Therefore, the changes caused by loading alone are difficult to determine empirically. In this study, the static and dynamic damping properties of air springs, which are a part of the air suspension system, were investigated by both experimental and finite element methods. While determining the static and dynamic damping properties, the reaction force values formed in the air springs due to different pressure and displacement were used. Differences were observed in spring constants obtained from experimental and analytical studies during spring back after compression. After reaching the minimum height, a deviation of about $10 \%$ in the spring constant was observed when the backward movement started, and then a deviation of less than $6 \%$ was obtained. In experimental tests and analytical studies, it has been observed that the deflection values between the spring constants obtained as a result of instantaneous loading remain below $4 \%$ and that FEA analysis can be used effectively in air spring analysis.
\end{abstract}

Keywords: Air spring, Finite element analysis, Cord-rubber composites, Hyper Elastic Materials, Ride comfort.

\footnotetext{
*Sorumlu Yazar: hasan@pegaairsprings.com
} 


\section{Giriş}

Sürüş konforunu arttırmak ve daha iyi yol tutuş performansı sağlamak için hava körükleri, demiryolu araçlarından (Bruni vd., 2011), lüks binek otomobillere (Sun vd., 2017), şehirlerarası otobüslere ve ticari araçlara (Lee vd., 2010). kadar birçok uygulamada yaygın olarak kullanılmaktadır. Hava yaylarının kullanımındaki bu artış, ayarlanabilir taşıma kapasitesi, azaltılmış ağırlık, değişken yay sertliği, aracın gövdesini, taşıdığı yükü ve araçta bulunan insanları düzensiz yol yüzeylerinden yayılan titreşimden koruması gibi sunduğu sayısız avantajdan kaynaklanmaktadır. Uzun süreli ve yüksek seviyeli titreşim, sürücünün rahatsızlığına ve yorgunluğuna, taşınan yükün deforme olmasına veya bir araç kazasına neden olur (Zhang vd., 2016). Bu sebep ile araç süspansiyonunu tasarlarken, yaylanma sertliği ve sönümleme özellikleri dikkate alınır. Araç farklı sürüş koşullarında çalıştıkça yay sertliği gereksinimleri değişir. Hızlanırken, frenlenirken ve viraj alırken, dinamik süspansiyonun yer değiştirmesini azaltmak için yay sertliği artırılmalıdır (Oman vd., 2010). Bununla birlikte, normal sürüş koşullarında, sürüş düzgünlüğünü iyileştirmek için süspansiyon sertliği daha yumuşak olmalıdır. Bu sebeple hava körüklerinin yaylanma davranışları yol uyarma sıklığına bağlı olarak non-lineer bir davranış sergiler ve hava körüklerin yaylanma özellikleri basınç, hacim, etkin alan ve politropik indeksin bir fonksiyonu olarak ifade edilir (Li vd., 2011). Bir hava yayı genellikle bir üst pleyt, bir kauçuk kompozit körük, bir piston ve bir sönümleme elemanından oluşur (Turna vd., 2018). Hava yayının özellikleri, büyük ölçüde piston şekline ve kauçuk kompozit körüğün bileşimine bağlıdır. Hava körüğü, içine doldurulan basınçlı havanın yol şartlarına göre sıkışması ve genleşmesi sayesinde değişken yüklere uygun bir şekilde tepki verir. Kauçuk hava süspansiyon sisteminin en kritik bileşeni katmanlı kompozit yapıdan oluşan elastomer esaslı kompozit yapıdır. Bu kısım, hava sızdırmazlığını sağlayan bir iç kauçuk tabakası (Yazıcı vd., 2017), ana iskelet yapısı üzerindeki gerilmeleri karşılayan iki veya daha fazla tabakadan oluşan kauçuk kaplı kord bezi ve farklı çevre koşullarına karşı koruma için kullanılan bir dış kauçuk tabakadan (Zhang vd., 2015) oluşan kompozit malzemelerden yapılmıştır. Kord bezi uygulanan yükü taşıyan kısım olduğu için, katmanların sarım açısı, kord bezi kalınlığı, kord ipleri arasındaki mesafe gibi özellikler körüğün deformasyonunu, iç gerilimini ve sertliğini büyük ölçüde etkiler (Ye vd., 2018). Kompozit yapının kesit görüntüsü şekil 1'de gösterilmiştir.

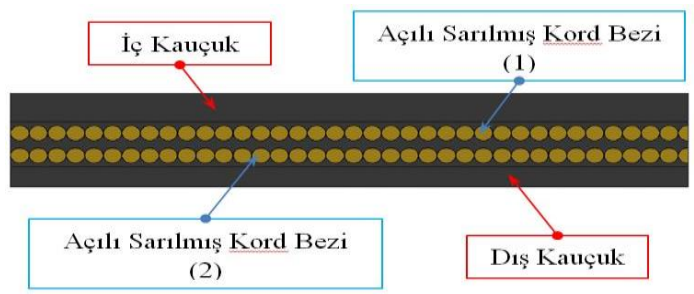

\section{Şekil 1. Kompozit yapı katmanların gösterimi}

Kord ipleri dokuma işleminden önce bükülür. Bükme ile korda belirli bir dayanım, uzama özelliği ve lastik içinde kullanımda belirli bir yorulma direnci kazandırmaktır. Bükme yönü sağa yapılıyorsa ' $S$ ', sola yapıllyor ise ' $Z$ ' olarak adlandırılır (Aytaç vd., 2008). Şekil 2'de kord ipinin büküm yönleri gösterilmiştir. Büküm işlemi ile ipliklere esneme özelliği kazandırılarak, üzerine yüklenen yükü belirli miktarda dağıtma ve yük kalktığında ise ilk haline dönme özelliği sağlanmaktadır.

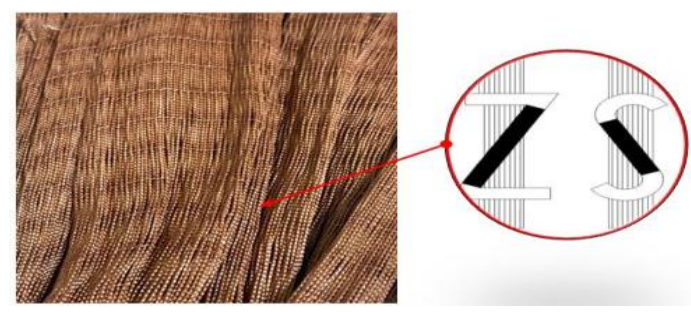

Şekil 2. Kord ipi büküm yönü şekilleri

Körükler hiperelastik malzemeden imal edilen parçalar oldukları için gerilme-gerinim (strees-strain) değerlerini analitik olarak belirlenmesi oldukça zor olan parçalardır (Lee vd., 2010), (Mars vd., 2004). Hava körüğünün yorulma ömrü, istatistiksel olarak birbirleriyle ilişkili birkaç faktörden etkilenir, ancak faktörler arasındaki ilişkiyi analitik yöntemler kullanılarak önceden belirlenmesinin zor olduğu görülmüştür (Oman vd., 2009), (Fatemi vd., 2002). Her ne kadar deneysel yöntemlerde doğruluk yüksek olsada, zaman kaybı ve yapıyı optimize etmek çok zordur (Guo vd., 2013). Son y1llarda hava körügünü hesaplamak ve analiz etmek için sonlu elemanlar yöntemi kullanılmaktadır. Hava körüğünün iç basınç değişimine bağl1 olarak körüğün geometrisindeki değişimin gözlenmesi ve körüğe uygulanan mekanik test (patlatma, çap büyüme, yorulma) sonuçlarının elde edilmesi geçmiş yıllarda prototip ile sağlanmıştır (Fischer vd., 1998). Hava körüğünün istenilen değerdeki yükleri taşımasında model üzerindeki kord açısı, kord ipleri aras1 mesafe, kord ipinin çap1 ve kompozit levha katlarından oluşan körüğün et kalınlığı etkilidir. Bu çalışmada hava süspansiyon körüklerinin statik ve dinamik yükler altındaki sönümleme özelliklerinin sonlu elemanlar yöntemi (FEA) ile belirlenmiştir.

\section{Materyal ve Metot}

\subsection{Hava Körüğünün Basınca Göre Değișimi}

Hava körüklerinde körük iç basıncındaki değişime bağ olarak gerilmeye maruz kalan esas yapı kauçuk ve kord bezinden meydana gelen kompozit yapıdır. Körük içindeki basınç değişimi radyal ve eksenel yönde hava körüğüne etki etmektedir. Hava körüğünde etkili olan radyal ve eksenel yükleme türlerinde eksenel yüklemenin büyük kısmı hava körüğünde yaylanma kuvvetini meydana getirir (Zhang vd., 2017). Eksenel kuvvetin küçük bir kısmı ise körüklerin eksenel bir yönde yüklenmesi sağlar. Körük yüksekliği değiştikçe, körükte oluşan reaksiyon kuvveti, körükte meydana gelen gerilmeler ve körük iç basıncı değişmektedir.

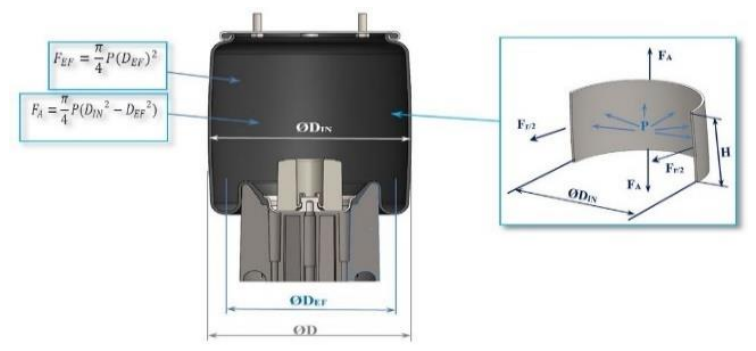

Şekil 3.Hava körügüunde oluşan radyal ve eksenel yükler

Araç üzerinde bağlanmış olan hava körüğünün çalışırken yol şartlarına anlık olarak tepki vermektedir. Değişken şartlarda oluşan titreşimi sönümleyerek daha konforlu bir sürüş ortaya 
çıkarır. Kompozit yapıdaki katmanlardan kauçuk malzemesi, kord bezine göre daha esnek ve yumuşak bir malzemedir. Hava körüğünde yüklemeye bağlı olarak oluşan iç basınç değişimleri sonucu körükte yükü taşıyan yapı aslında iki katmanlı olarak bulunan kord bezleridir. İki katmanlı kord bezi tabakasındaki kord ipleri birbirine zıt açılı olarak hava körüğünün yapısında bulunur. Şekil 4'te kord iplerinin iki katman olarak zıt açıyla konumlandırılması gösterilmiştir.

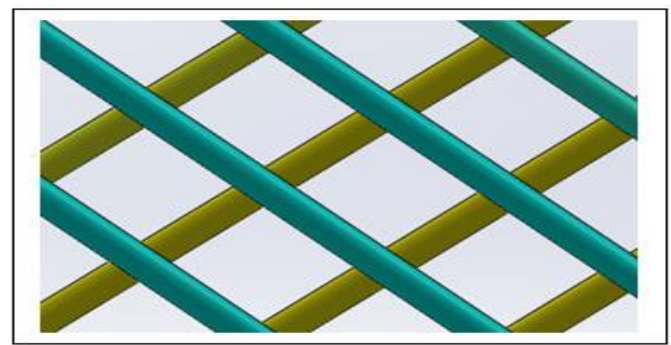

Şekil 4. Körükteki kord iplerinin zıt açılı konumu

Hava körüğünde, körük iç basınç durumuna göre 2 katman halinde bulunan kord iplerinin birbirleriyle yaptıkları zıt açı değişim göstermektedir. Körük iç basıncı artıkça kord bezleri arasındaki zıt açının değeri de artmaktadır.

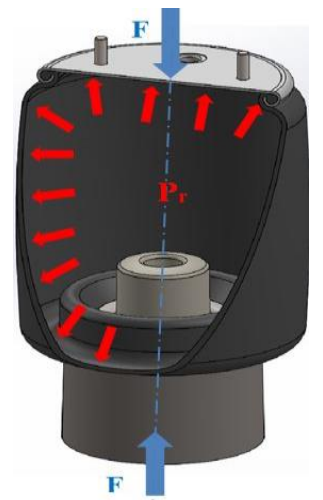

Şekil 5. Hava körüğ̈̈ne kuvvet uygulanması ve körükte oluşan iç basincın gösterimi

Hava körüğünde, kuvvete bağlı olarak kuvvet basınç arasındaki ilişki; $F(N)$ hava körüğüne etki eden kuvvet, $P_{r}$ (bar) hava körüğü içindeki değişime bağlı bağıl iç basınç, $A_{E F}\left(\mathrm{~mm}^{2}\right)$ etkin alanı ifade etmekte olup ve hava körüğ̈̈ $\mathrm{D}_{\mathrm{EF}}(\mathrm{mm})$ çap1 arasındaki ilişki denklem (1)'de gösterilmiştir (Kasim, 2012), $(\mathrm{Xu}, 2020)$

$$
F=P_{r} A_{E F}=\frac{\pi}{4} P_{r}\left(D_{E F}\right)^{2}
$$

Sıkıştırılmış gazın körük içi miktarı değişmezse, yük değişikliği hava körüğünün yükseklik değişikliğine neden olacak ve bu da hava körüğünün hacminde ve basıncında değişikliklere neden olacaktır. Bu değiş̧im sürecini ideal gaz denklemi (2) karşılar;

$$
\left(P_{r}+P_{a}\right)(V)^{n}=\left(P_{0}+P_{a}\right)(V)^{n}
$$

Yukarıdaki denklemde $\mathrm{P}_{\mathrm{a}}$ (bar) atmosfer basıncını, $\mathrm{P}_{0}$ (bar) hava körüğünün başlangıç basıncını, $\mathrm{V}_{0}$ hava körüğü başlangıç hacmini ifade etmektedir. $\mathrm{V}$ hava körüğünün herhangi bir konumdaki hacmidir. $P_{\mathrm{r}}$ (bar) herhangi bir basınçtaki hava körüğünün iç basıncıdır. $\mathrm{n}$ değeri ise politropik bir sabittir 1-1.4 arasında değer almaktadır.

$$
K=\frac{d F}{d X}=-n\left(A_{E F}\right) \frac{\left(P_{r}+P_{a}\right)}{V}\left(\frac{d V}{d X}\right)+P_{r} \frac{d A_{E F}}{d}
$$

Denklem (3)'e göre körüğe uygulanan kuvvetin körüğün deplasmanına göre türevi yay (sönümleme) katsayılarının bulunmasını analitik olarak sağlamaktadır. Denklem (3)'de $\mathrm{dV} / \mathrm{dX}$ hava körüğünün hacmindeki değișimi göstermekte olup $\mathrm{A}\left(\mathrm{mm}^{2}\right)$ ise hava körügünün etkili alan değişim oranıdır (Zhao vd.,2014).

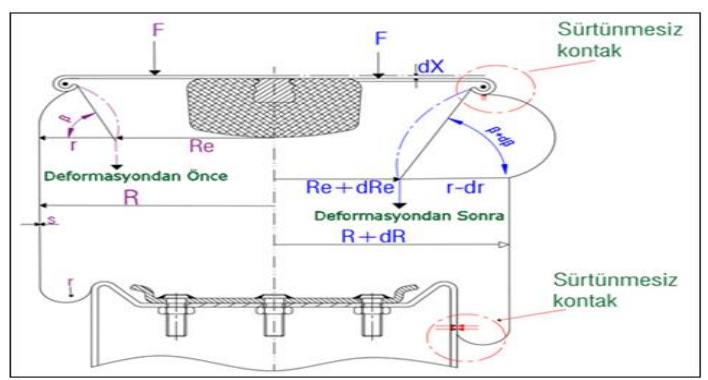

Şekil 6.Hava körüğü iç basınç değişiminin körükte meydana gelen değişimlerin matematiksel gösterimi

\subsection{Hava Körüğünün FEA Modelinin Oluşturulması}

Üretim aşamasında vulkanizasyon (basınç ve sıcaklık altında kauçuk malzeme içerisinde çapraz bağların oluşması işlemi) sonucu kauçuk ve kord bezinin birbirine yapışması sağlanarak üretilen kompozit malzeme, hava körüğünde yüklemelere maruz kalan esas yapıdır. Sonuç olarak, yorulma ömrü genellikle kompozit yapıdaki körüklerin üretim prosesine ve diğer parçalarla olan etkileşimine bağlıdır. İç basınç değerine göre gerilme değerlerini analitik yöntemlerle belirlemek oldukça zordur, çünkü körükte basınç artmasını sağlayan hava ve kompozit tabakalardan hiperelastik yapıdaki kauçuk nedeniyle analitik hesaplama yapmak zorlaşmaktadır. $\mathrm{Bu}$ nedenle körük üzerindeki değişimleri değerlendirmek ve belirlemek için sonlu elemanlar metodu kullanılmıştır. Hava körüğünün üzerine etki eden statik ve dinamik kuvvetlerin körük üzerinde oluşturduğu etkiyi daha iyi inceleyebilmek için ABAQUS 6.14 programı yardımıyla hava körüğünü sonlu elemanlar analizine tabii tutarak körüğün üzerindeki gerilme değerleri daha net gözlemlenmiştir. Hava körüğünün basınç ve yükseklik değişimine bağlı olarak yaptığı harekette körükte meydana gelen kuvvet, basınç ve deplasman değişimlerinin daha net bir şekilde gözlemlemek mümkün olmaktadır. Kauçuk yapısı itibariyle esnek bir yapıya sahip olan hiperelastik bir malzeme olarak kabul görür. Hava körüğünün iç basınç değerinin değişimini sağlayan hava, analiz sırasında sıkıștırılabilir malzeme olarak tanımlanır. Körük içinde havanın sıkışabilir olması ve kauçuğun hiperelastik malzeme olması kompozit yapının hareketinin doğrusal olmamasına sebep olur bu durumda analiz sırasında körükte oluşacak değişim hakkında tahminleri zorlaştırmaktadır. Sonlu elemanlar modelini hava körüğüne uygulayıp doğrusal olmayan bir analiz gerçekleştirerek hareketleri daha net gözlemlemek mümkün olmaktadır (Chen vd., 1994), (Sarığlu vd, 2019). Çalışmamızda kamyon, çekici vb. araçlarda çok fazla kullanılan metal pistonlu hava körüğü modeli tercih edilmiştir. Hava körüğü modelleme işleminde sadece üst pleyt, alt piston ve kompozit kısımdan meydana gelen kısımlarının modellemesi gerçekleştirildi, bu üç parçanın modellenmesi ile körük bütünlüğü sağlanmaktadır. Sonlu elemanlar analizinde model 
üzerinde bulunan pleyt ve alt kısımda bulunan piston rijit parça olarak kabul edildi. Hava körüğünün analizi farklı kılan bir başka durumda körükteki kauçuğun hiperelastik malzeme olmasıdır. Hiperelastik bir malzemenin mekanik özelliklerinin tanımlanması metalik malzemelerden oldukça farklıdır. Hiperelastik malzemenin mekanik özellikleri Mooney Rivlin modeline göre belirlenmiştir (Jamshidi vd., 2006). Hiperelastik bir malzeme için gerinim enerji yoğunluğu fonksiyonu $U$ denklem (4)'de belirtilmiştir.

$$
U=C_{10}\left(I_{1}-3\right)+C_{01}\left(I_{2}-3\right)+\frac{1}{D}\left(J^{e l}-1\right)^{2}
$$

Denklem 4'te bulunan $\mathrm{C}_{10}, \mathrm{C}_{01}$ ve $\mathrm{D}$ değerleri malzemenin test edilmesiyle elde edilen süper elastik malzeme sabitleridir. $\mathrm{J}_{\mathrm{el}}$ elastik hacimsel oranıdır, $\mathrm{I}_{1}$ denklem (5) ve $\mathrm{I}_{2}$ denklem (6) birinci ve ikinci gerinim (strain) değişmezleri değerleridir.

$$
\begin{gathered}
I_{1}=\lambda_{1}{ }^{2}+\lambda_{2}{ }^{2}+\lambda_{3}{ }^{2} \\
I_{2}=\left(\lambda_{1} \lambda_{2}\right)^{2}+\left(\lambda_{2} \lambda_{3}\right)^{2}+\left(\lambda_{1} \lambda_{3}\right)^{2}
\end{gathered}
$$

Denklem (5) ve denklem (6)'de $\lambda_{1}, \lambda_{2}$ ve $\lambda_{3}$ üç yöndeki gerilme katsayılarıdır. Hava körüğünün modelini oluşturan kompozit yapının içinde polyamid 66 ile yapılan kord bezi bulunduğundan, kord bezleri kauçuk içine gömülmüş halde bulunur (Wenku vd.,2009). Kord katmanı yapısındaki inşaat demiri ünitesi, hava körüğü kompozit malzemesini oluşturmak için kauçuk kabuk modeline gömülür (Shahzad vd., 2015). Çalışmamızda hava körüğü simülasyonun'da, kord takviyeli yapı inşaat demiri modeli olarak kabul edildi. Hava körüğünde kauçuk içine gömülü olan naylon fiber kord, kauçuk malzemesinin mekanik özelliklerini arttırmaktadır. Kauçuk ve kordun mekanik parametreleri tablo 1'de verilmiştir.

Tablo 1. Hava körüğü yapısal özellikleri

\begin{tabular}{l|c|c}
\hline \multicolumn{1}{c|}{ Parametre } & Değer & Birim \\
\hline Kord bezi katman sayısı & 2 & - \\
\hline Kompozit parça kalınlı̆̆ & 5 & $\mathrm{~mm}$ \\
\hline 1.kord bezi açısı & 45 & $\circ$ \\
\hline 2.kord bezi açısı & -45 & $\circ$ \\
\hline Kord ipleri arası mesafe & 0.39688 & $\mathrm{~mm}$ \\
\hline Bar başına alan & 0.049 & $\mathrm{~mm}^{2}$ \\
\hline
\end{tabular}

Körük içi yüksek basınçlarda hava körüğü sertleşir ve fazla sıkıştırılamaz. Körük içindeki havanın sıkışabilirliği nedeniyle oluşan yükte bir artış ile dikey yönde muazzam bir sapma olduğu açıkça görülebilir. Sıkıştırılmış kauçuk körükte yer değiştirmeyi kısıtlasa bile, sıkıştırılabilir hava körüğün deforme olmasına izin verir. $\mathrm{Bu}$ nedenle, belirli bir yük için, havalı süspansiyon sistemlerinde oluşması istenmeyen performanslardan kaçınmak için uygun körük iç basıncı yeterli miktarda sağlanmalıdır. Hava körüğü modelinin CAD dosyası bilgisayarda Solidworks programında yüzey modelleme olarak oluşturulmuştur. Sonlu elemanlar analizi için kullanılacak hava körüğü modeli çizilirken tamamen açık halde yani piston tabanı ve üst bağlantı parçası yüzeyi arası mesafenin $\mathrm{H}=650 \mathrm{~mm}$ yükseklikte çizimi gerçekleştirilmiştir. Hava körüğünün oluşturulan parçaları için gerekli olan malzeme özelliklerinin programa veri olarak girilmesi gerekmektedir. Analiz için

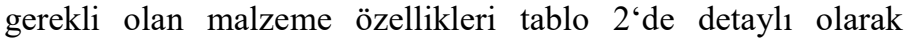
verilmiştir. Hava körüğü kısa sürede sıkıştırıldığından ve kısa sürede genişlediğinden körükten dışarıya 1Sı transferi yoktur. Sistemin çalışması adyabatik olarak kabul edilir. Hava körüğünün çalışması sırasında, körük piston üzerinde hareket eder. Bir hava körüğünün mekanik davranışı sadece geometrik doğrusallık ve malzeme doğrusallığını değil, aynı zamanda sınır koşullarının doğrusallığını da kapsar. Polyamid66 fiber kord takviyeli kauçuk kompozit, elastik, ortotropik ve homojen bir malzeme olarak kabul edilebilir.

Tablo2.Hava körüğ̈̈ analizi için malzeme özellikleri

\begin{tabular}{l|c|c}
\hline \multicolumn{1}{c|}{ Malzeme } & Değer & Birim \\
\hline Kord ipi & & \\
\hline Elastisite modülü & 4640 & $\mathrm{MPa}$ \\
\hline Poisson oranı & 0.3 & \\
\hline Yoğunluk & $1.16 \times 10^{-9}$ & $\mathrm{~T} / \mathrm{mm}^{3}$ \\
\hline Kauçuk & & \\
\hline$C_{10}$ & 0.48485 & \\
\hline$C_{01}$ & 0 & \\
\hline D & 0 & \\
\hline Hava & & \\
\hline Gaz sabiti (R) & $6.34 \times 10^{3}$ & $\mathrm{Kj} / \mathrm{kgK}$ \\
\hline Sicaklık (T) & $-273.15+25$ & $\mathrm{~K}$ \\
\hline Havanın ağırlığ & 0.044 & \\
\hline
\end{tabular}

Hava körüğü silindirik yapıdadır ve körükte kıvrımların etkisi göz ardı edilir ancak bu durumun sonuçlar üzerinde etkisi mevcuttur. Bir aktif veya uyarlanabilir havalı süspansiyon sistemi tasarlanırken, süspansiyonun analitik modeli, belirli bir uygulama için etkili kontrolörlerin tasarlanmasında önemli bir rol oynar. Hava körüğü analizinde, körük içindeki hava basıncı, körüğün hacminin yüksekliğe göre değişimi ve hiperelastik kauçuk malzemenin özellikleri önemli etkenlerdir. Yapmış olduğumuz analizde hava körüğünün kompozit kısmında meydana gelen gerilme, deplasman ve kuvvet değerlerini gözlemlemektir. Malzeme tanımlaması yapılırken hava körüğünü körük kısmını oluşturan malzemelerin tanımlaması FEA (sonlu elemanlar analizi) analiz programına veri girişi gerçekleştirilmiştir. İlgili yazılımda kauçuk için malzeme özellikleri Mooney Rivlin metoduna göre oluşturulmuştur. Kord bezinin elastik yapıda olmasının avantajı körük üzerinde yük ve basınç kalktığı zaman körüğün tekrar ilk haline dönmesini sağlar ve bu durum sayesinde hem körük yapısı bozulmaz hem de körük dayanıklılık kazanır. Hava körüğü içindeki sıkıştırılabilir havanın tanımlamasını yaparken havanın ağırlığı ve atmosfer basıncı değerlerinin FEA programına veri olarak girilmiştir. Hava için gerekli olan diğer parametreler ise mutlak sıfır sıcaklığı ve gaz sabiti değeridir. Hava körüğünde altta bulunan piston sabit olup piston her yönüyle hareketi kısıtlanıp ankastre olarak sabitlenir. Üst kısımda bulunan pleyt parçası sadece y doğrultusunda yani düşey doğrultuda hareket edebilen ve körük içi basınç değerine göre hareket mesafesi değişebilen yapıdır. Hareket kısıtlama konusunda asıl önemli olan kompozit malzemenin hareket kısıtlamalarını belirlemektir. Doğru tanımlamalar yapıldığı takdirde körük içi basınç değerine bağlı olarak körüğün analizi hakkında daha net bilgiler almak mümkün olacaktır. Körüğün kompozit kısmının hareket kısıtlamalarını belirlerken körüğün basınç ve yüklemeye bağlı olarak düşey doğrultuda hareketi sırasında, körüğün özellikle altta bulunan kıvrımlarının basınca bağlı dönme ve öteleme yaparak hareketi sağlaması gerekir. $\mathrm{Bu}$ sağladığı hareket sonucunda piston üzerinde sıvama hareketini yapması 
gerekmektedir. Analiz sırasında; deneysel olarak tahmin edilmesi güç olan çalışmalar sonlu elemanlar yardımı ile daha kolay gözlenebilmektedir. Bu amaçla körük üzerinde gerekli eleman ayrımı yapılarak mesh yapısı oluşturulmuştur. Burada amaç bir diferansiyel denklemin çözümünü kolaylaştırmaktır. Bundan dolayı sonlu elemanlar yönteminde elde edilecek sonuçların yaklaşım doğruluğu, ağ içerisinde kullanılan eleman tipine ve eleman sayısına bağlıdır. Eleman sayısı arttırılarak, eleman tipi değiştirilerek, mesh üretim yöntemi değiştirilerek veya mesh boyutları üzerinde oynanarak çözüm tekrarlanabilir.

\subsection{Deneysel Çalışmalar}

Deneysel çalışmalarda kullanılan metal pistonlu hava süspansiyon körüğü, kamyon ve çekicilerde kullanılmaktadır. Testler ve FEA çalışmaları için ürünün kullanıldığı araç ve tasrım girdileri çalışmalara başlanmadan önce üretici firmadan alınmıştır. Test şartları ilgili bilgiler üretici firmadan temin edilmiştir. Testlerde, özel bir test makinası kullanılarak, körük üst bağlantı pleyti, test makinesinin hareketli plakasına, piston tabanı sabit plakaya tutturulmuş ve sadece dikey yönde hareket etmesine izin verilmiştir. Körük testleri için gerekli deplasman değerleri, minimum ve maksimum çalışma aralığında elli milimetre artışlar ile beş farklı deplasman değerine bölünmüştür. Körük içerisindeki hava basıncı başlangıçta sıfır bardır ve test makinesinin başlangıç yüksekliği $650 \mathrm{~mm}$ olarak ayarlanmıştır. Deneysel analiz çalışmalarında hava yayı otomatik olarak belirlenen çalışma yüksekliklerine getirilerek farklı basınç değerleri $(1,2,3,4$ ve 5 bar) için testler yapılmıştır. Körüklerin içerisine gönderilen hava basıncı kararlı bir hale gelmeden ölçümler başlamamıştır. Beş farklı yükseklik için hava yaylarına 1 ile 5 bar arası basınçlı hava gönderilmiş ve düşey reaksiyon kuvvetleri ölçülmüştür. Elde edilen reaksiyon kuvvetine ve uygulanan yer değiştirme miktarına bağlı olarak düşey yönde oluşan yay katsayısı bulunmuştur. Tablo 3 , körüğe ait deneysel çalışmalardan elde edilen reaksiyon kuvveti değerlerini göstermektedir. Gazın sıkışması sonucu basınç ve reaksiyon kuvvetleri artar. Elde edilen kuvvet değerleri KiloNewton $(\mathrm{kN})$ olarak gösterilmiştir.

Tablo 3. Deneysel çalışmalardan elde edilen reaksiyon kuvveti değerleri

\begin{tabular}{c|c|c|c|c|c}
\hline \multirow{2}{*}{$\begin{array}{c}\text { Basınç } \\
\text { (bar) }\end{array}$} & \multicolumn{5}{|c}{ Deplasman değerleri (mm) } \\
\cline { 2 - 6 } & $\mathbf{5 0}$ & $\mathbf{1 0 0}$ & $\mathbf{1 5 0}$ & $\mathbf{2 0 0}$ & $\mathbf{2 5 0}$ \\
\hline 1 & 3.16 & 4.21 & 5.06 & 5.54 & 5.67 \\
\hline 2 & 2.42 & 6.64 & 9.42 & 11.05 & 11.23 \\
\hline 3 & 4.26 & 10.27 & 14.10 & 16.07 & 18.41 \\
\hline 4 & 5.21 & 13.50 & 18.51 & 21.75 & 23.24 \\
\hline 5 & 6.17 & 15.25 & 24.84 & 30.74 & 29.55 \\
\hline
\end{tabular}

\section{Araştırma Sonuçları ve Tartışma}

\subsection{Statik sönümleme özelliklerinin Fea ile incelenmesi}

Statik analiz, bir yapının üzerindeki yükü veya dışarıdan gelen herhangi bir etkinin yapıda meydana getirdiği değişimin (deplasman, gerilme, moment etkisi) güvenli olup olmadığını hakkında bilgi almamızı sağlayan analiz türüdür. Mühendislikte hemen hemen her konuda statik analiz kullanılmaktadır. Çalışmamızda ağır ticari araçlarda kullanılan hava körüğünün statik sönümleme özelliğinin sonlu elemanlar modelinde incelemesini gerçekleştirilmiştir. Belirli yüksekliklerde ve farklı iç basınç $(1,2,3,4$ ve 5 bar) değerlerinde hava körüğünde meydana gelen gerilme, çap büyümesi, reaksiyon kuvveti, yaylanma özellikleri vb. veriler elde etmeyi amaçlanmıştır. FEA modeli sınır koşullarının tanımını, hava yayına ait pistonunun alt tabanından sabitlenerek ve serbestlik derecesi sifira ayarlanmıştır. Körüğe ait üst bağlantı plakası sadece dikey yönde hareket edecek şekilde tanımlanmış ve serbestlik derecesi bir olarak ayarlanmıştır. Hava körüğü içerisine ilgili basınç değerine uygun hava verilerek çalışma durumuna ayarlanır. Üst bağlantı plakasının (şase) dikey yer değiştirme parametresi gerçek araç koşullarına uygun olacak şekilde kullanılarak, hava körüğünün dikey hareket mesafesi ayarlanır. FEA analizi; hava yayını belirtilen basınç değerlerine şişirmek, dikey yönde hareketi tanımlamak ve belirtilen deplasman değerine uygun bir şekilde sıkıştırmak şeklinde üç adım olacak şekilde tanımlanmıştır. Statik analiz sırasında hava körüğü başlangıç olarak $\mathrm{H}=650$ (mm) yüksekliktedir. Hava körüğüne farklı iç basınç $(1,2,3,4$ ve 5 bar) değerleri ve farklı deplasmanlar (50, $100,150,200$ ve $250 \mathrm{~mm}$ ) uygulanmıştır. Böylece, analiz edilen körük üzerinde farklı iç basınç ve yer değiştirmelere bağlı olarak oluşan gerilme değerlerinin neden olduğu yük dalgalanmaları sonucunda dikey rijitlik performansları ve reaksiyon kuvveti değerleri belirlenmiştir. Fea analizi sonucunda düşey yönde oluşan reaksiyon kuvveti değerleri tablo 4' de gösterilmiştir. Elde edilen kuvvet değerleri Kilo-Newton $(\mathrm{kN})$ olarak gösterilmiştir. Hava yayının deplasmana bağlı olarak sıkışma miktarı arttıkça içeride hapsolmuş gazın basıncı nedeniyle reaksiyon kuvvetleride artmıştır.

\section{Tablo 4.Hava körüğü analizi için gerekli olan malzeme özellikleri}

\begin{tabular}{c|c|c|c|c|c}
\hline \multirow{2}{*}{$\begin{array}{c}\text { Basınç } \\
\text { (bar) }\end{array}$} & \multicolumn{5}{|c}{ Deplasman değerleri (mm) } \\
\cline { 2 - 6 } & $\mathbf{5 0}$ & $\mathbf{1 0 0}$ & $\mathbf{1 5 0}$ & $\mathbf{2 0 0}$ & $\mathbf{2 5 0}$ \\
\hline 1 & 3.33 & 4.43 & 4.96 & 5.65 & 5.78 \\
\hline 2 & 2.49 & 6.98 & 9.62 & 11.28 & 11.82 \\
\hline 3 & 4.18 & 10.07 & 14.39 & 16.92 & 18.05 \\
\hline 4 & 5.49 & 13.78 & 19.48 & 22.89 & 24.46 \\
\hline 5 & 6.36 & 15.89 & 25.09 & 29.28 & 31.10 \\
\hline
\end{tabular}

Dikey sıkıştırma miktarına göre, FEA ve deneysel çalışmalardan elde edilen reaksiyon kuvveti değerlerinin değişimi karşılaştırmalı olarak Şekil 7'de gösterilmiştir. İki çalışma arasında yaklaşık \%4 civarında bir sapma değeri çalışmanın güvenilirliği açısından önemlidir.

FEA ve deneysel çalışmalarda elde edilen reaksiyon kuvvetlerini değerlendirdiğimizde, $650 \mathrm{~mm}$ montaj yüksekliğinde elde edilen reaksiyon kuvveti değerleri daha düşüktür. Kord-kauçuk kompozit yapısı piston ile daha az etkileşime girer, yanal ve yukarı doğru uzama özgürlüğüne sahiptir. Sıkışma başladığında körük ile piston arasındaki etkileşime bağlı reaksiyon kuvveti artış gösterir. Körükteki basınç artışı, körükteki gerilme değerlerini de arttırır. Kauçuk kompozit yapı hiperelastik olduğu için gerilme değerlerinde meydana gelen değişikliklere direnir. Kord ipleri, kauçuk malzemeye göre yüksek stres değerlerinden daha fazla etkilenir. Hava körügüunde 5 bar basınç altında meydana gelen reaksiyon kuvveti ve gerilme değerlerine ait analiz sonuçları, $50 \mathrm{~mm}, 100$ $\mathrm{mm}, 150 \mathrm{~mm}, 200 \mathrm{~mm}$ ve $250 \mathrm{~mm}$ deplasman değerleri için elde edilmiştir. 

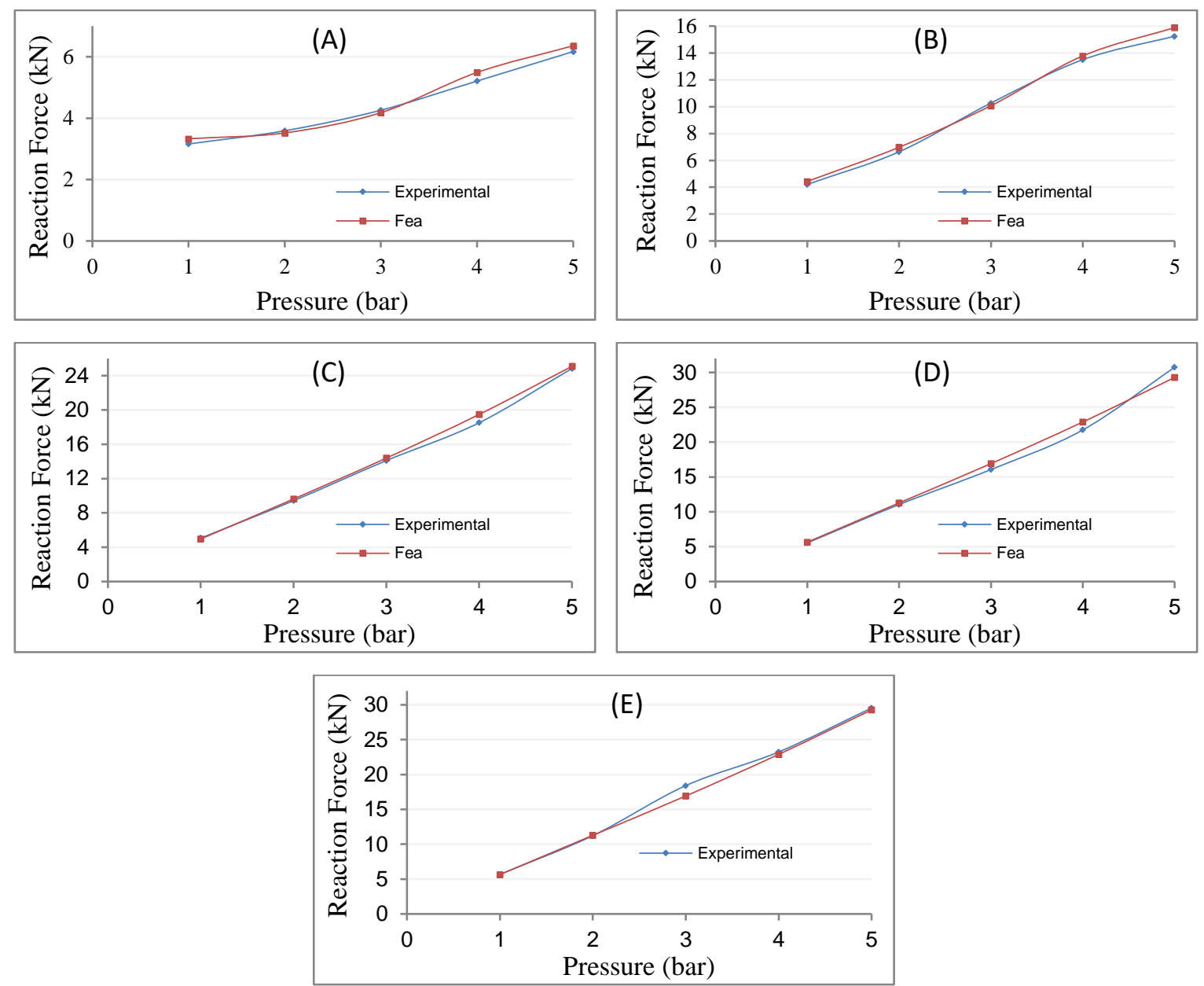

Şekil 7. FEA ve Deneysel Çalışma Reaksiyon Kuvveti Karşılaş̧tırma Grafikleri: (A) 50 mm, (B) 100 mm, (C) 150 mm, (D) 200 mm, (E) $250 \mathrm{~mm}$

Sekil 8'de 50 mm'lik deplasman sonucunda oluşan reaksiyon kuvvetleri ve gerilme değerlerina ait FEA sonuçları gösterilmiştir. Özellikle hava körüğünün kompozit kauçuk kısmının orta bölgesinde gerilme yığılmaları artmaktadır. Bu bölgede kauçuk kompozit yapı yanlara ve yukarı doğru zorlanarak hareket etmektedir.

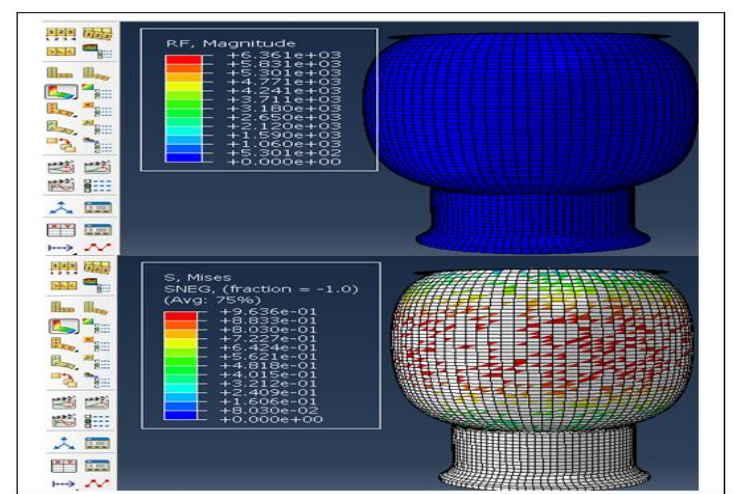

Şekil $8.50 \mathrm{~mm}$ deplasmana bağl olarak oluşan reaksiyon kuvveti ve gerilme değerleri

Kompozit yapıda en fazla gerilmeye maruz kalan kısımda kord ipleri daha fazla zorlanmaya maruz kalmaktadır. Kord bezi üzerine vulkanize olan iç ve dış kauçuk, tek bir yapı gibi birlikte hareket ederek oluşan gerilmeleri karşılarlar. Ana taşıyıcı kord bezi olduğu için, sarım açısı, katmanların birbirine Basınç arttıkça katmanlar arasındaki hareketlilikten dolayı, kord ipleri birbirinden ayrılmaya zorlanmaktadırlar. Körügün hareketi göre konumu ve proses șartları basınç altındaki zorlanmalarda oldukça önemlidir. Şekil 9, şekil 10, şekil 11, şekil 12'de deplasmana bağlı reaksiyon kuvvetleri ve gerilme değerlerini gösteren sonuçlara verilmiştir. Hava körügünün metal üst bağlantı plakası ile piston üzerinde hareket eden kısımdaki hareket serbestliği körüğün dış çap kısmına göre daha azdır. Hareketleri belirli yönlerde sinırlandırılmıştır. Özellikle kompozit kauçuk yapının orta bölgesinde alanda yapı daha serbet hareket ederken, daha fazla gerilmeye maruz kalır. $\mathrm{Bu}$ bölgede kauçuk kompozit yapı yanlara ve yukarı doğru serest hareket etmektedir.

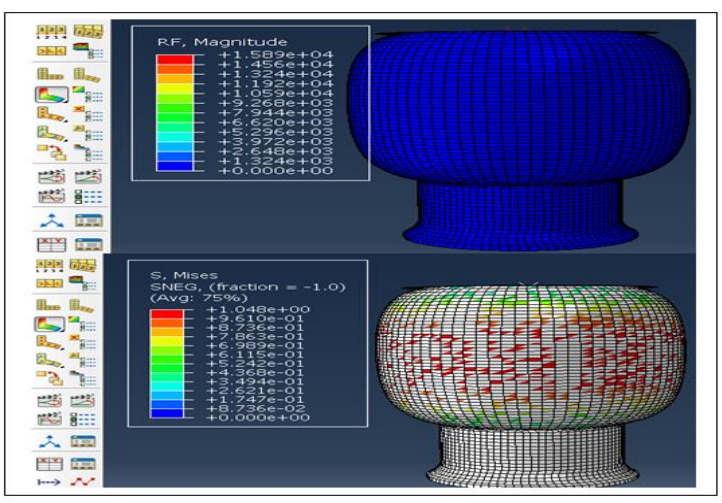

Şekil 9. $100 \mathrm{~mm}$ deplasmana bağlı olarak oluşan reaksiyon kuvveti ve gerilme değerleri

esnasında kord iplerinin hem birbirleri ile hemde kauçuk ile sürtünmesinden dolayı sıcaklıklığıda arttırmaktadır. 


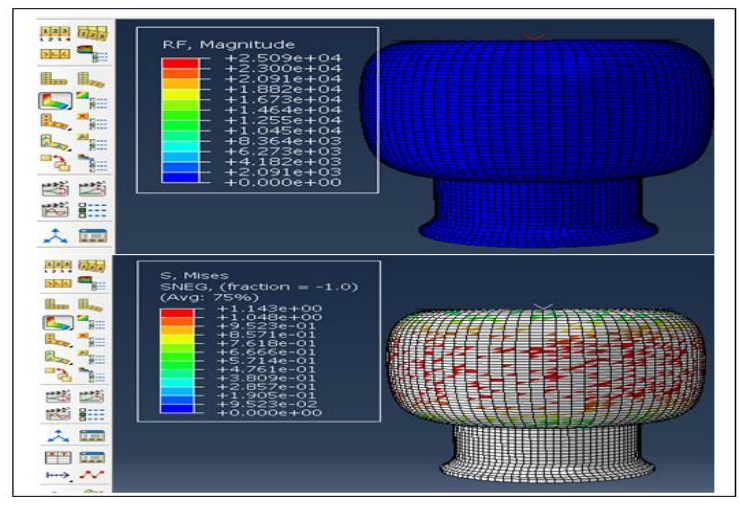

Şekil 10. $150 \mathrm{~mm}$ deplasmana bă̆lı olarak oluşan reaksiyon kuvveti ve gerilme değerleri

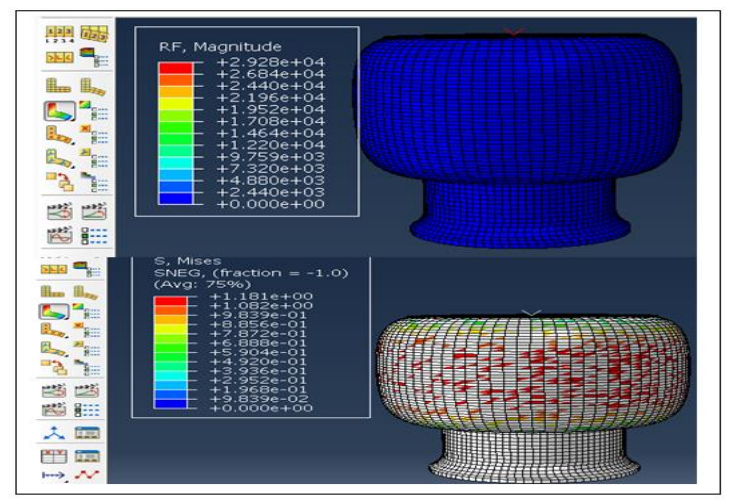

Şekil 11. $200 \mathrm{~mm}$ deplasmana bağll olarak oluşan reaksiyon kuvveti ve gerilme değerleri

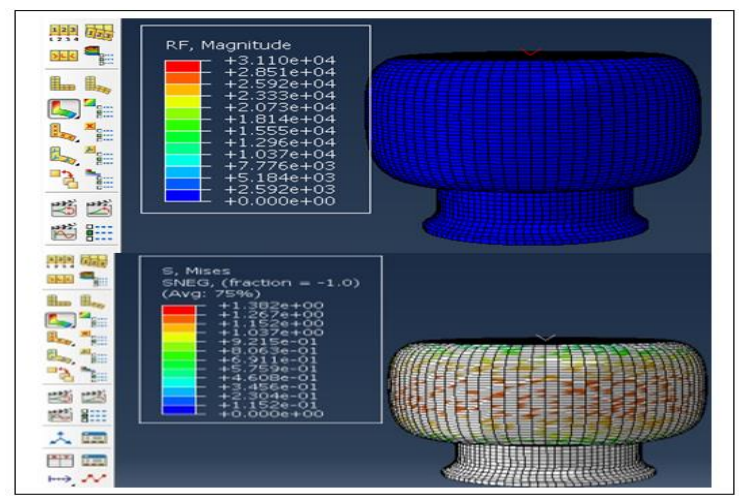

Şekil 12. $250 \mathrm{~mm}$ deplasmana bağll olarak oluşan reaksiyon kuvveti ve gerilme değerleri

Denklem (3) kullanılarak hem FEA ile hemde deneysel olarak hava körüğünün yay(sönümleme) katsayısı değerleri hesaplanmıştır. Kamyon ve çekicilerin süspansiyon sisteminde kullanılan hava körüklerinin tasarım özellikleri (dayanıklılık, tepki kuvvetleri, yer değiştirmeler vb.) FEA analizi ile belirlenmiştir. Deneysel saha testleri ile analiz sonuçları arasında \%4'ün altındaki sapma elde edilmiştir. Körükler şasi ve araç altında dingile monte edilerek çalışır. İç basınç ve sıkıştırma oranları, çalışma sırasındaki yük ve yol koşullarına göre değişir. Körüklerin sönümleme özellikleri, sertliği ve frekansı, iç basınca ve yer değiştirmeye bağlıdır (Eskandary vd., 2016). Aracın yükleme ve yol koşullarına bağlı olarak, körük iç basıncında sürekli değişiklikler olur ve bu değişiklikler reaksiyon kuvvetlerini oluşturur. Yapılan çalışmada, aracın yük durumu ve hareket halinde olmaması dikkate alınarak, farklı yüksekliklerde ve iç basınçlarda yapılan testlere bağlı olarak yay katsayıları (rijitlik) elde edilmiştir. Körüklerin yaylanma özelliklerinin analitik çözümlerle belirlenmesi, tasarım sürecine büyük katkı sağlar. Hava körüğünün yay(sönümleme) katsayısı değerleri hem deneysel hemde FEA çalışması ile 5 bar'a ait yay katsayı değerleri elde edilerek şekil 13' de gösterilmiştir. Elde edilen değerler $\mathrm{N} / \mathrm{mm}$ 'dir.

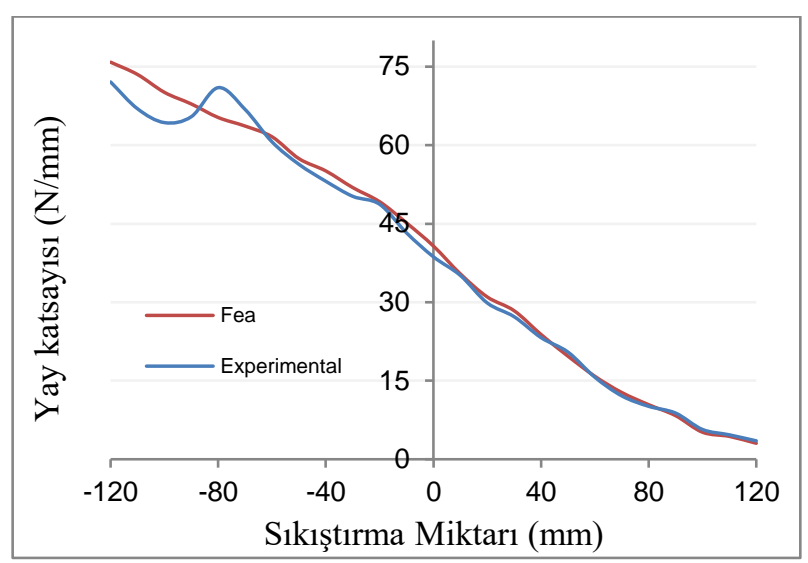

Şekil 13. Hava körüğünün yay katsayısı değerlerinin karşılaştırılması

Deneysel ve analitik çalışmaların yaylanma özelliklerinde özelikle açılma sırasında farklılıklar gözlenmiştir. Minimum yüksekliğe geldikten yaklaşık $50 \mathrm{~mm}$ geri gelene kadar $\% 10$ civarında sapma görülmüş, sonrasında bu oran yaklaşık \%6 olarak elde edilmiştir. Kord ipleri arasındaki gerilme sıkışma anında daha fazla artmıştır. Başlangıç pozisyonun agelmeye başladığ 1 anda korbezine vulkanize kauçuk hareketlenmiştir. $\mathrm{Bu}$ bölgede oluşan sapmanı sebebi olarak değerlendirilir.

\subsection{Dinamik sönümleme özelliklerinin Fea ile incelenmesi}

Dinamik analiz, zamana bağlı olarak yüklerin analizi, rastsal titreşimlerin analizi, harmonik yüklemelerin analizi ve pik/şok yüklemelerin analizi gibi alanları kapsamaktadır. Örneğin bir yapısal sistemin belirli frekans aralığına sahip titreşime nasıl yapısal cevap verdiği bu alana girmektedir. Hava körügüne uygulayacağımız dinamik analizde hareket halindeki aracın kasisten geçmesi anını düşünerek milisaniye gibi kısa bir zaman diliminde körük üzerine belirli bir yükün yüklenmesi ve körügün bu yüklemeye karşı oluşturacağı tepki kuvveti, deplasman değeri ve deformasyon yapısını incelenmiştir. Daha detaylı bir örnek verecek olursa 8 (ton) bir aracın kasisten geçme anında 0.1 (milisaniye) gibi kısa sürede $6000(\mathrm{~mm} / \mathrm{s})$ hızla beraber araç ağırlığının 1/4 'ünün araçtaki bir adet hava körüğü üzerine yüklenmesi durumunun analizi gerçekleştirildi. Tablo 5 'te hava körüğünün başlangıç değerleri verilmiş olup dinamik analizde farklı iç basınç (1, 2, 3, 4 ve 5 bar) değerlerinde gerçekleştirildi.

Tablo 5. Dinamik analiz için hava körüğü başlangıç değerleri

\begin{tabular}{c|c|c|c|c}
\hline $\begin{array}{c}\text { Yükseklik } \\
(\mathbf{m m})\end{array}$ & $\begin{array}{c}\text { Çap } \\
(\mathbf{m m})\end{array}$ & $\begin{array}{c}\text { Kalınlık } \\
(\mathbf{m m})\end{array}$ & $\begin{array}{c}\text { Yük } \\
(\mathbf{k N})\end{array}$ & $\begin{array}{c}\text { Zaman } \\
(\mathbf{m s})\end{array}$ \\
\hline 334 & 265 & 5 & 2 & 0.1 \\
\hline
\end{tabular}

Tablo 5'te belirtilen özellikler ile farklı basınç değerlerinde gerçekleştirilen dinamik analiz sonucunda hava körügüüde anlık olarak deformasyonlar meydana gelmiştir. 


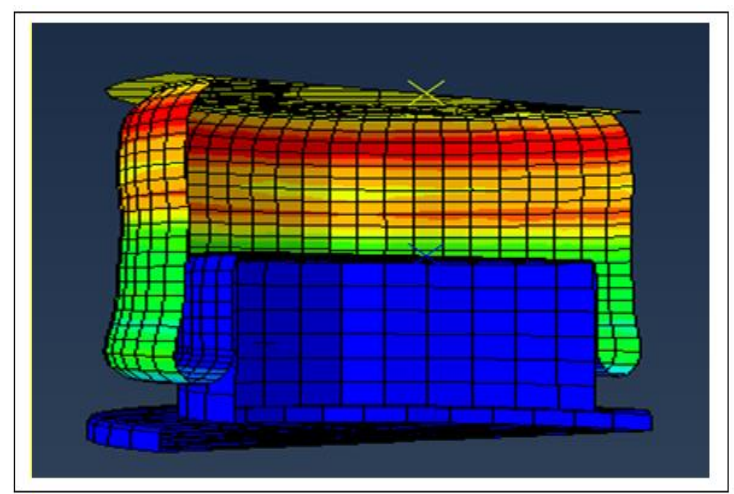

Şekil 15. Dinamik analiz sonucu deformasyona uğramış hava körüğü görünümü

Hava körüğünün en düşük 1 bar ve en yüksek 5 bar iç basınçtaki dinamik analiz sonuçlarını detaylıca değerlendirerek körüğün karakteristik davranışı belirlenmiştir.

1 bar basınçta hava körüğü üzerinde yük binmesinden önce ve körüğün üzerine ani bir şekilde kuvvetin uygulanması sonucu oluşan deformasyondaki hareketin vektörel gösterimi şekil 16, şekil 17 ve şekil $18^{\prime}$ de aşamalı olarak gösterilmiştir. Hava körüğünün analizi doğrusal olmadığı için hava körüğünün kompozit kısmındaki hareket doğrusal şekilde olmamaktadır. Sonlu elemanlar analizi sayesinde doğrusal olmayan harekete bağlı olarak körüğün sönümleme anındaki hareketi hakkında daha fazla bilgiye sahip olabiliriz.

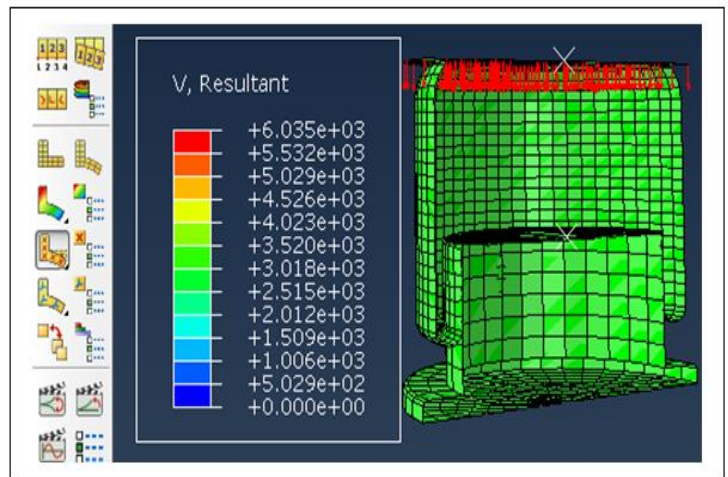

Şekil 16.Körük başlangıç hareketinin vektörel gösterimi (1 bar)

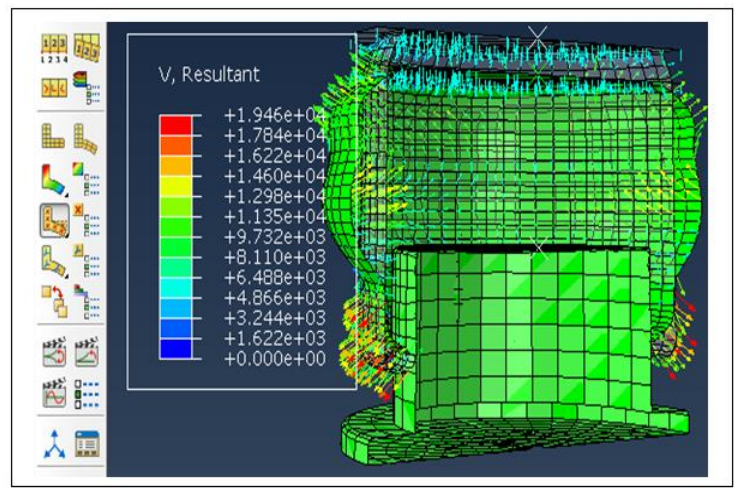

Şekil 17.Ani yükleme durumunun vektörel gösterimi (1 bar)

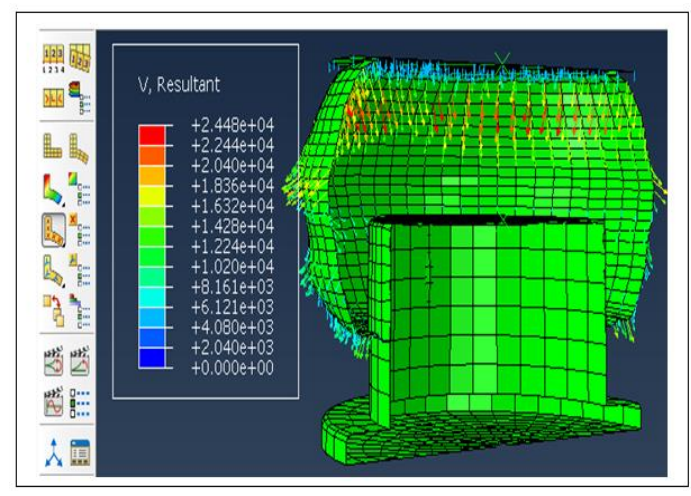

Şekil 18. Oluşan deformasyonun vektörel gösterimi (1 bar)

Hava körüğünün 1 bar iç basınç değerinde bulunurken üzerinde uygulanan ani yüklemeye karşısında hava körüğünde oluşan reaksiyon kuvveti şekil 19'da gösterilmiştir. Şekilsel olarak belirgin deformasyon kauçuk kompozit yapının orta bölgelerinde meydana gelmiștir. En zayıf bölge olarak değerlendirilmesi doğru değildir, sadece diğer bölgelere göre daha fazla hareket serbestliğine sahiptir.

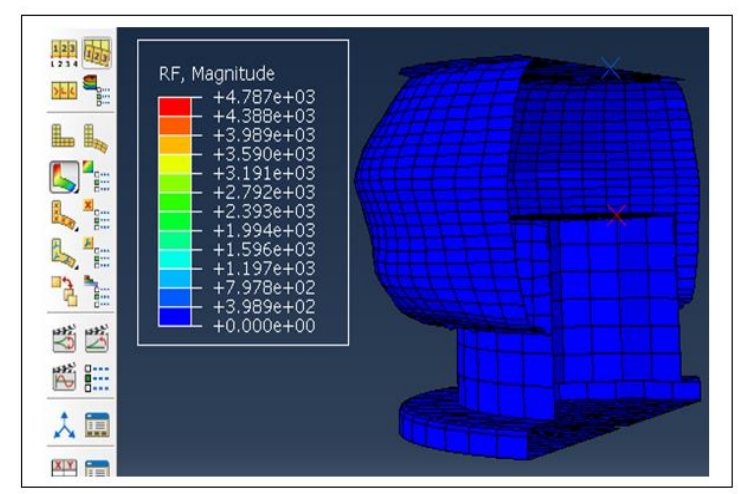

Şekil 19. 1 bar iç basinçta oluşan reaksiyon kuvveti ve deformasyon

1 Bar iç basınca sahip körük üzerine etki eden yüke bağlı olarak oluşan kinetik enerji değişimi şekil 20'de gösterilmiştir. Kinetik enerjideki değişim megajoule (MJ), zaman saniye (s) birimi ile gösterilmiştir.

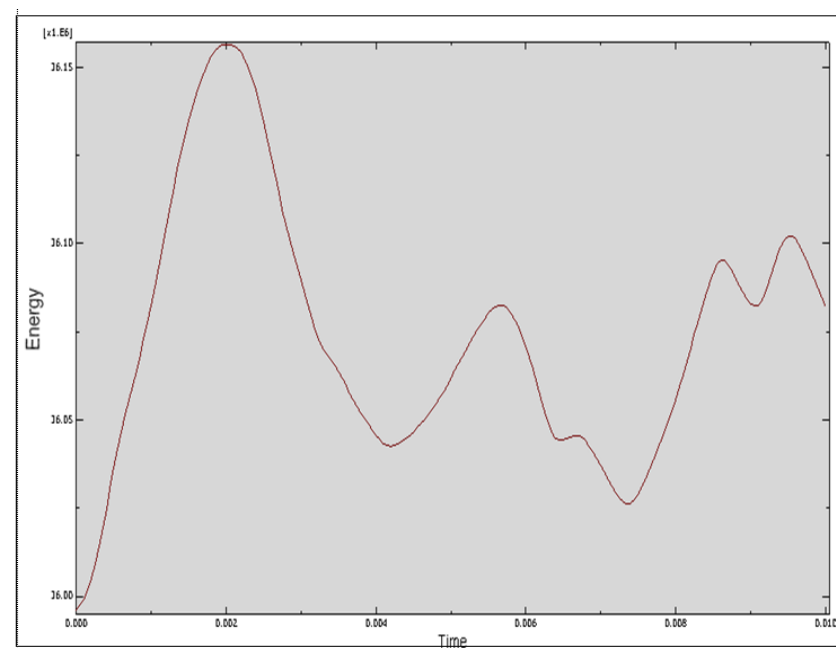

Şekil 20.1 bar basınçta hava körüğ̈̈nün kinetik enerji değişim grafiği

20 kN'luk yükün, $0.1 \mathrm{~ms}$ gibi kısa sürede hava körüğüne etki etmesi ile 0.02 s'lik bir sürede 16.17 MJ'luk bir enerji açığa 
çıkmıştır. Körük üzerindeki ani yükleme ile sıkışan hava ve kompozit malzemenin elastik davranışı yardımıyla açığa çıkan enerji miktarı hızla azalmıştır.

5 bar iç basınç değeri altında hava körüğünün yapısında meydana gelen yer değiştirme sonuçları vektörel olarak sırasıyla gösterilmiştir.

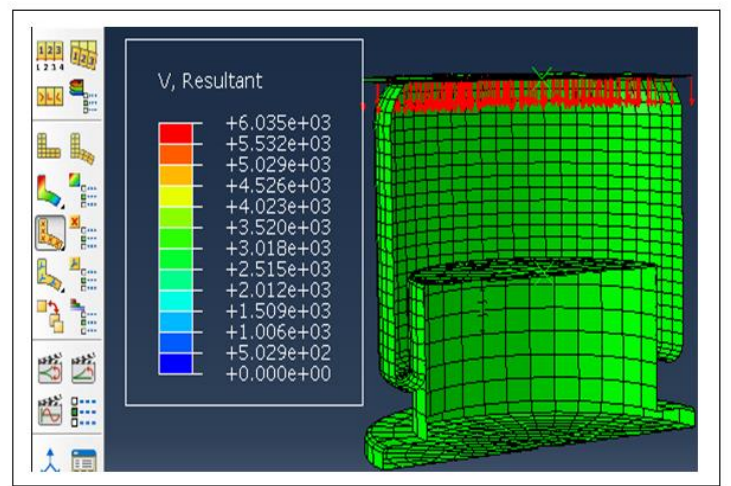

Şekil 21. Körük başlangıç hareketinin vektörel gösterimi (5 bar)

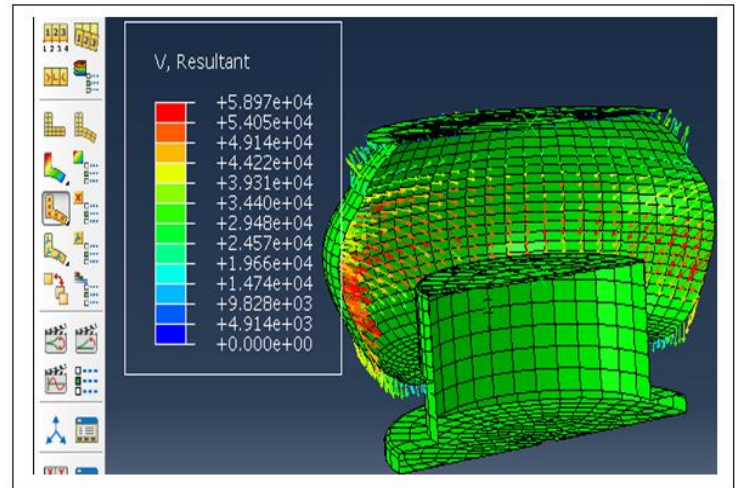

Şekil 22. Ani yükleme durumunun vektörel gösterimi (5 bar)

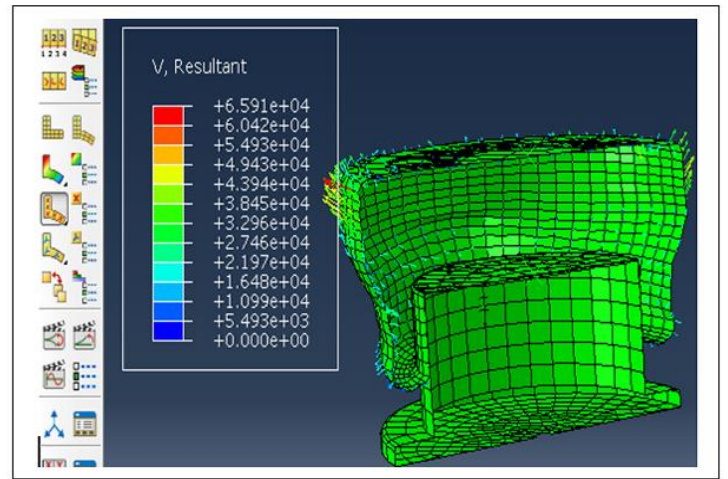

Şekil 23. Oluşan deformasyonun vektörel gösterimi (5 bar)

Hareket doğrusal olmadığı için 1 bar ve 5 bardaki hareket vektörlerinin aynı zaman dilimindeki yönleri birbirinden farklıdır. Hava körüğünde 5 bar basınçtaki dinamik analiz sonucu oluşan reaksiyon kuvveti değeri aşağıdaki şekil 24 'te gösterilmiştir. Körük içi basınç değeri yüksek olduğu için hava körügünde meydana gelen reaksiyon kuvvet değeri de 1 barlık basınca göre daha yüksektir.

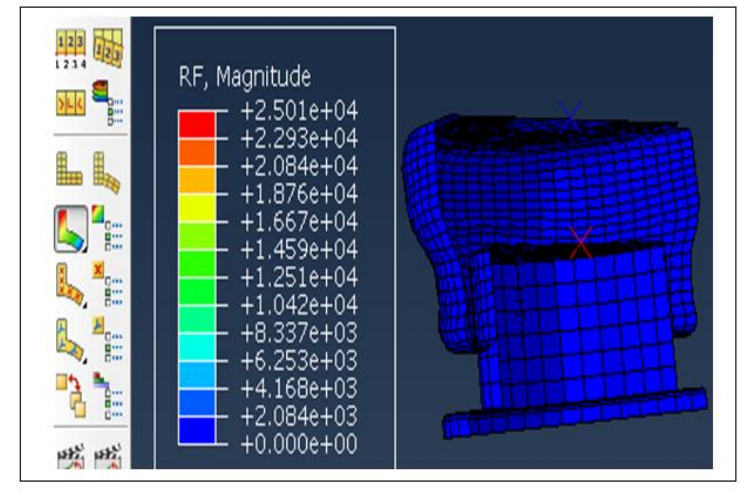

Şekil 24. 5 bar iç basınçta oluşan reaksiyon kuvveti ve deformasyon

Hava körüğü yüksek sönümleme özelliği sayesinde ani yüklemeler karşı yükü yavaşlatmakta ve yoldan araca etki eden hareketleri sönümleyerek daha konforlu sürüş sağlamaktadır. Așağıdaki grafikte 5 bar basınca sahip olan hava körüğünün 20 kN'luk ve $0.1 \mathrm{~ms}$ gibi kısa sürede $6000 \mathrm{~mm} / \mathrm{s}$ hızla hava körüğüne etki eden yükün hava körüğünün sönümleme özelliği ile modeldeki kinetik enerji (MJ)-zaman (s) değişimi şekil 25' deki grafikte gösterilmiştir.

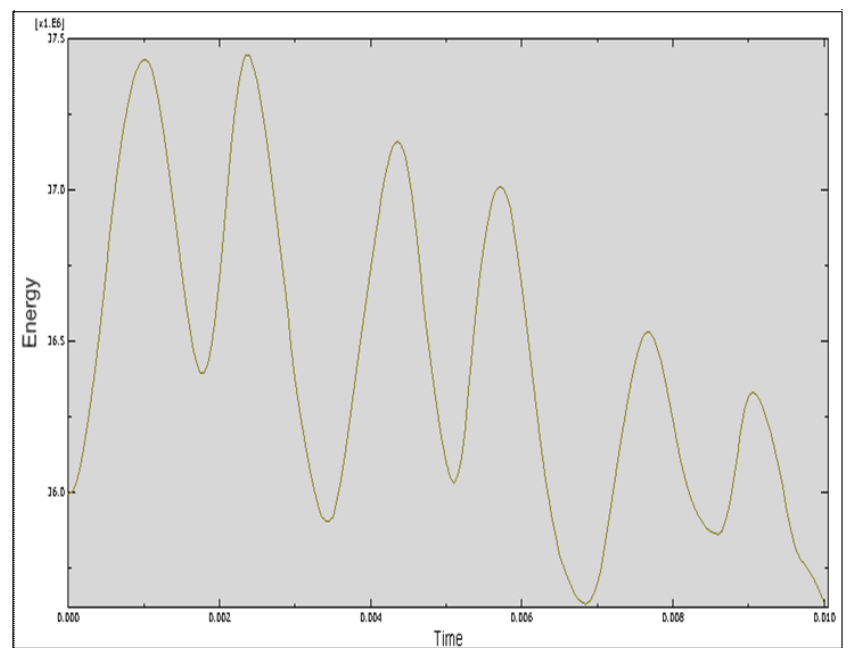

Şekil 25. 5 bar basinçta hava körüğ̈̈nün kinetik enerji değişim grafiği

Körük üzerine uygulanan ani yüklemeler karşısında hava körüŭg̈nde oluşan reaksiyon kuvveti değerleri tablo 6'da verilmiştir. Farklı iç basınçlarda (1, 2, 3, 4 ve 5 bar) $6000 \mathrm{~mm} / \mathrm{s}$ hızla ile yapılan ani yükleme sonucu düşey yönde (Y yönünde) oluşan reaksiyon kuvvetleri incelendiğinde körük iç basınç değeri artışına bağlı olarak düşey yöndeki reaksiyon kuvveti de yükselmektedir. Dinamik testler $90 \mathrm{~mm}$ deplasman değerine göre gerçekleştirilmiştir.

Tablo 6: Dinamik analiz sonucu elde edilen reaksiyon kuvveti değerleri

\begin{tabular}{c|c}
\hline $\begin{array}{c}\text { Basınç } \\
\text { (bar) }\end{array}$ & $\begin{array}{c}\text { Reaksiyon Kuvveti } \\
\text { (kN) }\end{array}$ \\
\hline 1 & 4.79 \\
\hline 2 & 10.85 \\
\hline 3 & 13.70 \\
\hline 4 & 18.05 \\
\hline 5 & 25.01 \\
\hline
\end{tabular}


Hava körüklerine uygulanan dinamik analiz sonucu elde edilen veriler incelendiğinde, körüklerin metal yaylardan daha iyi sönümleme özelliğine sahip olan otomotiv parçaları olduğu gözükmektedir. Hava körükleri yaylardan daha konforlu sürüş sağlamakta ve araç yüksekliğini sürüş şekline göre ayarlayabilmektedir bu sayede araçlarda özel donanım olarak bulunabilmektedir. Sonlu elemanlar analizi ile elde edilen düşey yöndeki reaksiyon kuvveti (F) ve dinamik yay katsayısı değerleri tablo 7'de verilmiştir. Reaksiyon kuvveti değeri arttıkça yay katsayısının değeri de artmaktadır.

\section{Tablo 7: Dinamik analiz sonucu elde edilen ya katsayısı değerleri}

\begin{tabular}{c|c}
\hline $\begin{array}{c}\text { Basınç } \\
\text { (bar) }\end{array}$ & $\begin{array}{c}\text { Yay Katsayısı } \\
\text { (N/mm) }\end{array}$ \\
\hline 1 & 79.87 \\
\hline 2 & 180.56 \\
\hline 3 & 228.3 \\
\hline 4 & 300.83 \\
\hline 5 & 416.83 \\
\hline
\end{tabular}

Elde edilen sonuçlar arasındaki yakınlık, hava körügünün minimum ve maksimum çalışma yüksekliği arasında birçok testin yapılmış olmasına ve malzeme özelliklerinin çok iyi tanımlanmış olmasına bağlıdır. FEA analizinin havalı yay analizinde etkin bir şekilde kullanılabileceği çalışmalardan görülmektedir.

\section{Sonuç}

$\mathrm{Bu}$ çalışmada hem deneysel hem de sonlu eleman analiz modelleri sayesinde kauçuk kompozit yapıdan oluşan hava körüğünün statik yükler ve anlık yükleme durumundaki sönümleme davranışı hakkında aşağıdaki bilgiler elde edildi:

1. Hava körüğünün 5 bar basınç altında statik olarak yapılan deneysel ve FEA çalışmalarından elde edilen yay sabitleri arasında ortalama \%6'lı bir sapma meydana gelmiştir. Ancak hava körüğünün sıkışması ve geri gelerek açılması anında farklılıklar gözlenmiştir. Hava körüğü geri gelme hareketine bağladığ 1 andan yaklaşık $50 \mathrm{~mm}$ lik bir mesafede yaylanma oranındaki sapma yaklaşı $\% 10$ civarındadır. Statik durumda birbirine yakın değerler elde edilmesi tasarım sürecince Fea çalışmalarından güvenli bir şekilde tanımlanabileceğini göstermiştir.

2. Hava körüğünün dinamik anlık yükleme durumları için yapılan deneysel ve FEA çalışmaları arasındaki sapma miktarı \%4 civarında olması, basınca ve yüklemeye bağlı reaksiyon kuvvetlerinden dolayı oluşan parametrelerin tahmin edilmesi için kolaylık sağlamıştır.

3. Abaqus programında sonlu elemanlar analizinin yardımı ile modellenmiş olan hava körüğünün sönümleme sırasındaki hareketi, reaksiyon kuvveti, körükte meydana gelen diğer değişimler rahatlıkla gözlenmiştir. Hava körügünün sönümleme özelliği hakkında bilgi edinilmiştir.

4. Hava körüğünü oluşturan kompozit yapıya ait malzeme özelliklerinin doğru yapılmış deneylerden elde edilmiş olması sapma miktarını azaltmıştır.

5. Hava körüğünün çalışması esnasında içerisindeki basınçlı havanın malzeme özelliklerinin Fea programına tanımlanması analizin güvenilirliğini arttırmıştır. FEA çalışması için iç basıncı oluşturan havanın atmosferik basıncı, mutlak sıcaklık, havanın ağırlığı ve hava basıncı etkisinin yaratacağı alan doğru tanımlanmalıdır.

6. FEA çalışması sayesinde, hava yayındaki bölgesel gerilme, kuvvet ve yer değiştirme gibi değerlerle ilgili daha fazla sonuç elde edilebilir.

7. Çalışmamızda kauçuk kompozit yapıdaki kord bezlerinin kauçuk malzemeye göre aşırı gerilmelerden daha fazla etkilendiği görülmüştür. Kord lifleri, basınç artışı durumunda körüğün aşırı genişlemesini sınırlar ve körüğün darbesinden kaynaklanan yükleri taşıyan ana unsurdur.

8. Deneysel ve fea çalışmalarında oluşan sapmaların sebebi olarak prototip üretim sürecinde oluşabilecek hatalardan olarak değerlendirilmiştir.

9. Elde edilen veriler doğrultusunda gelecekte yapılması planan çalışmalarda, hava körüklerinin modellenmesi, kord bezinin sarım açısının değişmesi, kompozit malzeme kalınlığının değişmesi vb. durumlardaki deneysel sonuçları, sonlu elemanlar analizi ile daha hızlı bir şekilde elde edebilir ve model üzerinde meydana gelen sorunları prototip ihtiyacı duymadan tasarım aşamasında çözüleceği görülmüştür.

\section{Teșekkür}

$\mathrm{Bu}$ çalışma için gerekli olan kompozit numunelerinin temini ve test ekipmanlarının kullanımını sağlayan Pega Otomotiv Arge Merkezi çalışanlarına teşekkür ederiz.

\section{Kaynakça}

Bruni S., Vinolas J., Berg M., Polach O., Stichel S. (2011). Modelling of suspension components in a rail vehicle dynamics context. Vehicle System Dynamics, Volume 49(7), 1021-1072.

Sun X., Yuan C., Cai Y., Wang S., Chen L. (2017). Model predictive control of an air suspension system with damping multi-mode switching damper based on hybrid model. Mechanical Systems and Signal Processing, 94, 94-110.

Lee, S.J. (2010). Development and analysis of an air spring model. International Journal of Automotive Technology,11, 471-479.

Zhu H., Yang J., Zhang Y., Feng X. (2016). A novel air spring dynamic model with pneumatic thermodynamics, effective friction and viscoelastic damping. Journal of Sound and Vibration, 408, 87-104.

Oman S., Fajdiga M., Nagode M. (2010). Estimation of airspring life based on accelerated experiments. Materials \& Design, 31(8), 3859-3868.

Li Z., Shen X., Li M., Guo J., Wu Y., Jiang W. (2011). Analysis on mechanical characteristics of diaphragm air spring for semi-active suspension. International Conference on Consumer Electronics, Communications and Networks, CECNet 2011 - Proceedings, 2, 4781-4784.

Turna E., Kafkas F., Şeker U., Yücesu H. (2018). Kauçuk Hava Süspansiyon Körüklerinin Üretim Yöntemi ve Yorulma Ömrünün Ürün Kalitesi Üzerine Etkisinin Belirlenmesi. Journal of Polytechnic, 0900(4), 759-764.

Yazıcı M., Kapucu OA., Kasım H., Can Y. (2017). Experimental Investigation on Fatigue Life of Cord-Rubber Composites. Avrupa Bilim ve Teknoloji Dergisi, Ejosat Aralık Özel Sayı, 90,16-21.

Zhang X., Zhao G. (2015). Overview of experimental studies on strength problem of rubber material. 5th International 
Conference on Advanced Engineering Materials and Technology, 13-22.

Ye J., Huang H., He C., Liu G. (2018). Analysis of Vertical Stiffness of Air Spring Based on Finite Element Method. MATEC Web Conferences, 153, 06006.

Aytaç, A., Yılmaz B., Deniz V. (2008). Kord Bezi Üretiminde büküm yönünün etkilerinin farklı deney tasarımı yöntemleri ile incelenmesi. Dokuz Eylül Üniversitesi İşletme Fakültesi Dergisi, 9(1), 61-71.

Mars, W.V., \& Fatemi, A. (2004). Factors that affect the fatigue life of rubber: A literature survey. Rubber Chemistry and Technology, 77(3), 391-412.

Oman S., Nagode M., Fajdiga M. (2009). The material characterization of the air-spring bellows sealing layer. Matererial and Design, 30(4), 1141-1450.

Fatemi A., Mars WV. (2002). A literature survey on fatigue analysis approaches for rubber. International Journal of Fatigue, 24(9), 949-961.

Guo K., Li H., Chen S., Wang W., Cong F. (2013). Design of Stiffness for Air Spring Based on ABAQUS. Mathematical Problems in Engineering, 2013, 528218.

Fischer G., Streicher M., Grubisic V. (1998). Procedure for Validation Tests on Air Springs for Commercial Vehicles. SAE Technical Paper 982841.

Zhang Y., Zhu H., Yang J., Feng X., Ma Z. (2017). Nonlinear dynamic model of air spring with a damper for vehicle ride comfort. Nonlinear Dynamics, 89,1545-1568.

Kasım H. (2012). Kabin Körüklerinin Tasarımı, Üretim Ve Test Parametrelerinin Belirlenmesi. Makine Mühendisliği, Yüksek Lisans Tezi, Uludağ Üniversitesi, Bursa,Türkiye, 2012. https://acikerisim.uludag.edu.tr/handle/11452/10028

Xu L.(2020). Theoretical modeling of the vertical stiffness of a rolling lobe air spring.Science Progress, 103(3), 1-21.

Zhao J., Xie Z., Wong PK., Xu T., He F. (2014). Analysis of automotive rolling lobe air spring under alternative factors with finite element model. Journal of Mechanical Science and Technology, 28(12), 5069-5081.

Chen JS., Satyamurthy K., Hirschfelt IR. (1994).Consistent finite element procedures for nonlinear rubber elasticity with a higher order strain energy function. Computers \& Structures, 50(6), 715-727.

Sarığlu B., Durmuş A. (2019). Manufacture and Testing of Air Springs Used in Railway Vehicles. Arabian Journal for Science and Engineering, 44(9), 7967-7977.

Jamshidi M., Afshar F., Shamayeli B. (2006). Evaluation of cord/rubber adhesion by a new fatigue test method. Journal of Applied Polymer Science, 101(4), 2488-2494.

Wenku S., Wan J., Ying H., Weimin Y., Hao Y., Zubin L. (2009). Finite element analysis of an air spring concerning initial pressure and parameters of cord fabric layer. PACIIA 2009 - 2009 2nd Asia-Pacific Conference on Computational Intelligence and Industrial Applications, 1, 496-499.

Shahzad M., Kamran A., Siddiqui MZ., Farhan M. (2015). Mechanical Characterization and FE Modelling of a Hyperelastic Material. Materials Research, 18(5), 918-924.

Eskandary PK., Khajepour A., Wong A., Ansari M. (2016). Analysis and optimization of air suspension system with independent height and stiffness tuning. International Journal of Automotive Technology, 17, 807-816. 